\title{
A systematic review for pursuing the presence of antibiotic associated enterocolitis caused by methicillin resistant Staphylococcus aureus
}

\author{
Kentaro Iwata', Asako Doi ${ }^{2}$, Takahiko Fukuchi ${ }^{1}$, Goh Ohji ${ }^{1}$, Yuko Shirota ${ }^{3}$, Tetsuya Sakai ${ }^{4}$ and Hiroki Kagawa ${ }^{5}$
}

\begin{abstract}
Background: Although it has received a degree of notoriety as a cause for antibiotic-associated enterocolitis (AAE), the role of methicillin resistant Staphylococcus aureus (MRSA) in the pathogenesis of this disease remains enigmatic despite a multitude of efforts, and previous studies have failed to conclude whether MRSA can cause AAE. Numerous cases of AAE caused by MRSA have been reported from Japan; however, due to the fact that these reports were written in the Japanese language and a good portion lacked scientific rigor, many of these reports went unnoticed.
\end{abstract}

Methods: We conducted a systematic review of pertinent literatures to verify the existence of AAE caused by MRSA. We modified and applied methods in common use today and used a total of 9 criteria to prove the existence of AAE caused by Klebsiella oxytoca. MEDLINE/Pubmed, Excerpta Medica Database (EMBASE), the Cochrane Database of Systematic Reviews, and the Japan Medical Abstract Society database were searched for studies published prior to March 2013.

Results: A total of 1,999 articles were retrieved for evaluation. Forty-five case reports/series and 9 basic studies were reviewed in detail. We successfully identified articles reporting AAE with pathological and microscopic findings supporting MRSA as the etiological agent. We also found comparative studies involving the use of healthy subjects, and studies detecting probable toxins. In addition, we found animal models in which enteritis was induced by introducing MRSA from patients. Although we were unable to identify a single study that encompasses all of the defined criteria, we were able to fulfill all 9 elements of the criteria by collectively analyzing multiple studies.

Conclusions: AAE caused by MRSA — although likely to be rarer than previous Japanese literatures have suggested— most likely does exist.

Keywords: Methicillin-resistant Staphylococcus aureus, MRSA, Enterocolitis, Pseudomembranous colitis, Clostridium difficile

\section{Background}

Although numerous papers have been published to date on methicillin resistant Staphylococcus aureus (MRSA), its role in the pathogenesis of antibiotic-associated enterocolitis remains unclear. During the 1950s, Staphylococcus aureus was prime suspect in antibiotic-associated pseudomembranous enterocolitis [1]; however, since the identification of Clostridium difficile and its toxin as the

\footnotetext{
*Correspondence: kiwata@med.kobe-u.ac.jp

'Division of Infectious Disease, Kobe University Hospital, 7-5-2 Kusunokicho, Chuoku, 650-0017 Kobe, Hyogo, Japan

Full list of author information is available at the end of the article
}

primary cause of pseudomembranous colitis in the 1970s, S. aureus has all but been exonerated from the accusation [2-5]. In more recent years, the majority of cases involving antibiotic-associated enterocolitis (AAE) are considered to be caused by Clostridium difficile. In most countries, MRSA as a potential cause of enterocolitis is usually disregarded, if not rarely questioned [6,7].

On the opposite end of the spectrum, a fairly consistent number of MRSA enterocolitis cases have been reported from Japan since the late 1980s [8-10]. Unfortunately, most of these literatures were published in the Japanese language and therefore were rarely acknowledged by the 
greater international scientific community. The end result was the fueling of a misconception for AAE which lingers to this day [11].

The reports on the so-called MRSA enterocolitis in Japan may have misrepresented $C$. difficile infection (CDI), since routine stool cultures often fail to identify $C$. difficile. This is compounded by the fact that the mere presence of MRSA in stool does not prove its pathogenicity. In addition, oral metronidazole had not been approved for treating CDI in Japan until 2012 [12]. In previous years, oral vancomycin remained the only treatment method available, and many physicians could have mistakenly prescribed a treatment regimen for "MRSA enterocolitis" when in fact they were treating CDI.

In order to elucidate the true causality of MRSA for antibiotic-associated enterocolitis, and bridge the divide on the understanding of AAE among different nations, we conducted a systematic review on MRSA enterocolitis associated with the use of antibiotics.

\section{Methods}

\section{Search strategy and selection criteria}

We systematically searched MEDLINE/PubMed, Embase, the Cochrane Database of Systematic Reviews, and the Japan Medical Abstract Society database for articles available on the subject prior to March 2013. The Japan Medical Abstract Society database is the largest database for medical articles in Japan and contains over 5,000 journals. The repository also consists of over 7.5 million published articles and abstracts of scientific meetings dating back to 1983, written mainly in the Japanese language [13]. We decided to include this database since most reports on MRSA enterocolitis are in fact from Japan but written in the Japanese language and thus may hinder their chances of inclusion in other noteworthy databases. For Pubmed, Embase, and Cochrane, the keywords used for searches included the following: 'methicillin'/exp OR methicillin AND resistant AND ('staphylococcus'/exp OR staphylococcus) AND aureus OR 'mrsa'/exp OR mrsa

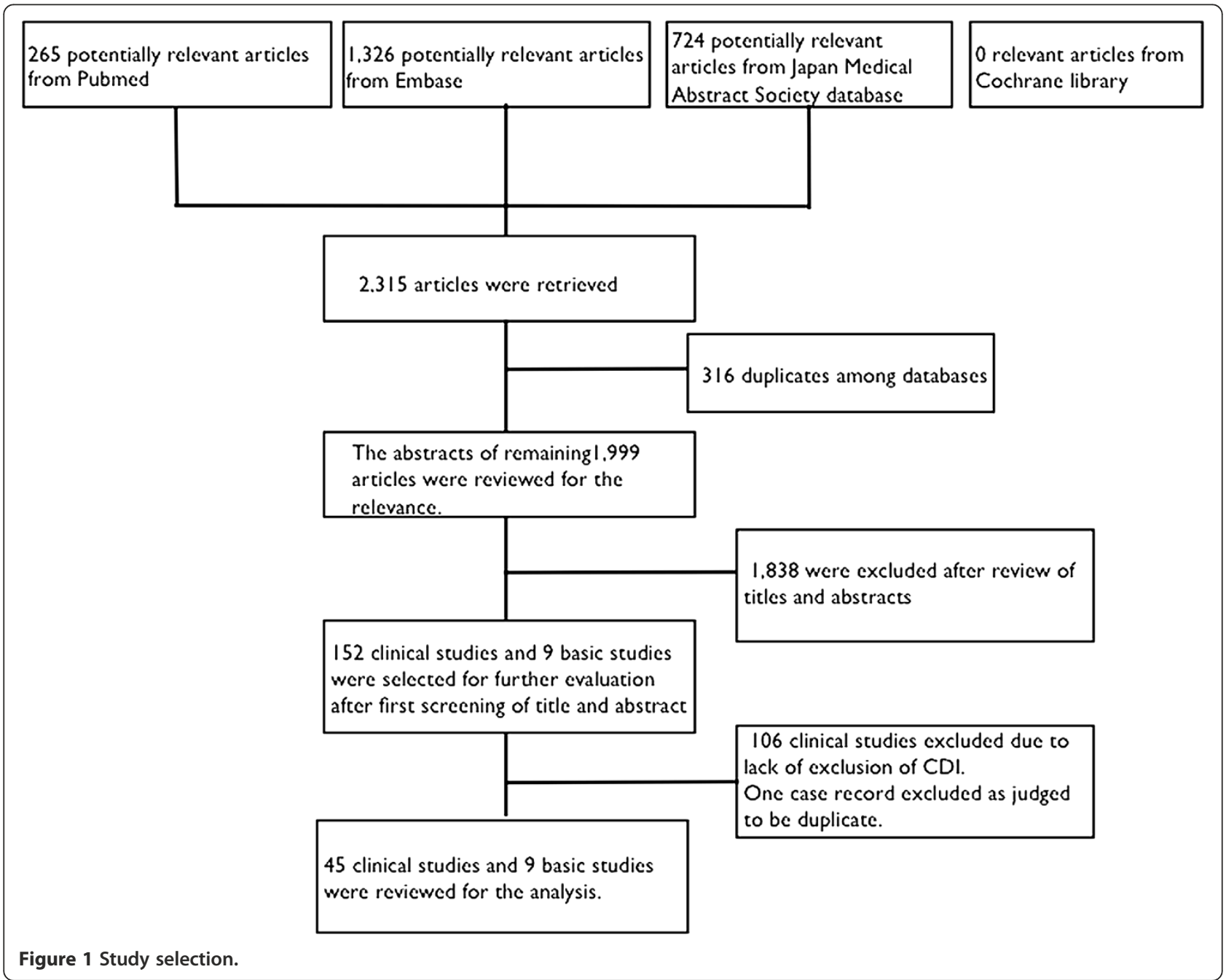


AND ('colitis'/exp OR colitis OR 'enteritis'/exp OR enteritis OR 'enterocolitis'/exp OR enterocolitis OR 'diarrhea'/ exp OR diarrhea). For the Japan Medical Abstract Society database, "methicillin resistant Staphylococcus aureus," or "MRSA" AND "choen" (meaning colitis in Japanese) were used for the search. Retrieved reports were also manually screened for further potentially relevant full articles. We included studies written in languages other than English, but excluded studies presented solely as abstracts for scientific conferences.

\section{Data extraction and evaluation}

We included original articles in which antibioticassociated MRSA enterocolitis was described. To supplement the clinical studies, we also sought basic scientific studies such as those using animals to strengthen the argument for pathogenesis of AAE caused by MRSA, using same search criteria. Eligible reports were independently reviewed for evaluation by two authors (K. I. and D. A.), who are both infectious diseases specialists, certified by the Japanese Association for Infectious Diseases. K. I. is also certified by the American Board of Internal Medicine on both Internal Medicine and Infectious Diseases.
Any disputes were resolved by discussion between these two parties.

In general, Koch's postulates is used for proving a given organism to be the pathogen of any given infectious disease; i.e., 1) the organism must be present in cases of the disease, 2) the organism can be isolated from the diseased host and grown in pure culture, 3) the organism from the pure culture must cause the disease when inoculated into a healthy subject, and 4) the organism must be reisolated from the diseased subject and shown to be the same organism as the originally inoculated organism [14]. Since MRSA can be found in the stool of healthy subjects, we avoided simply applying Koch's postulates to prove causality. Likewise, we did not merely apply guidelines proposed for the diagnosis of acute bacterial diarrheal illnesses, since these were developed for pathogens that readily cause outbreaks [14]. Rather, we modified and applied the methods used by Högenauer et al. for proving the causality of Klebsiella oxytoca as a cause of AAE [15]; i.e., 1) exposure to antibiotics prior to the onset of diarrhea, 2) endoscopic findings consistent with AAE, 3) Gram staining or other microscopic examination of stool or colon consistent with AAE caused by Gram

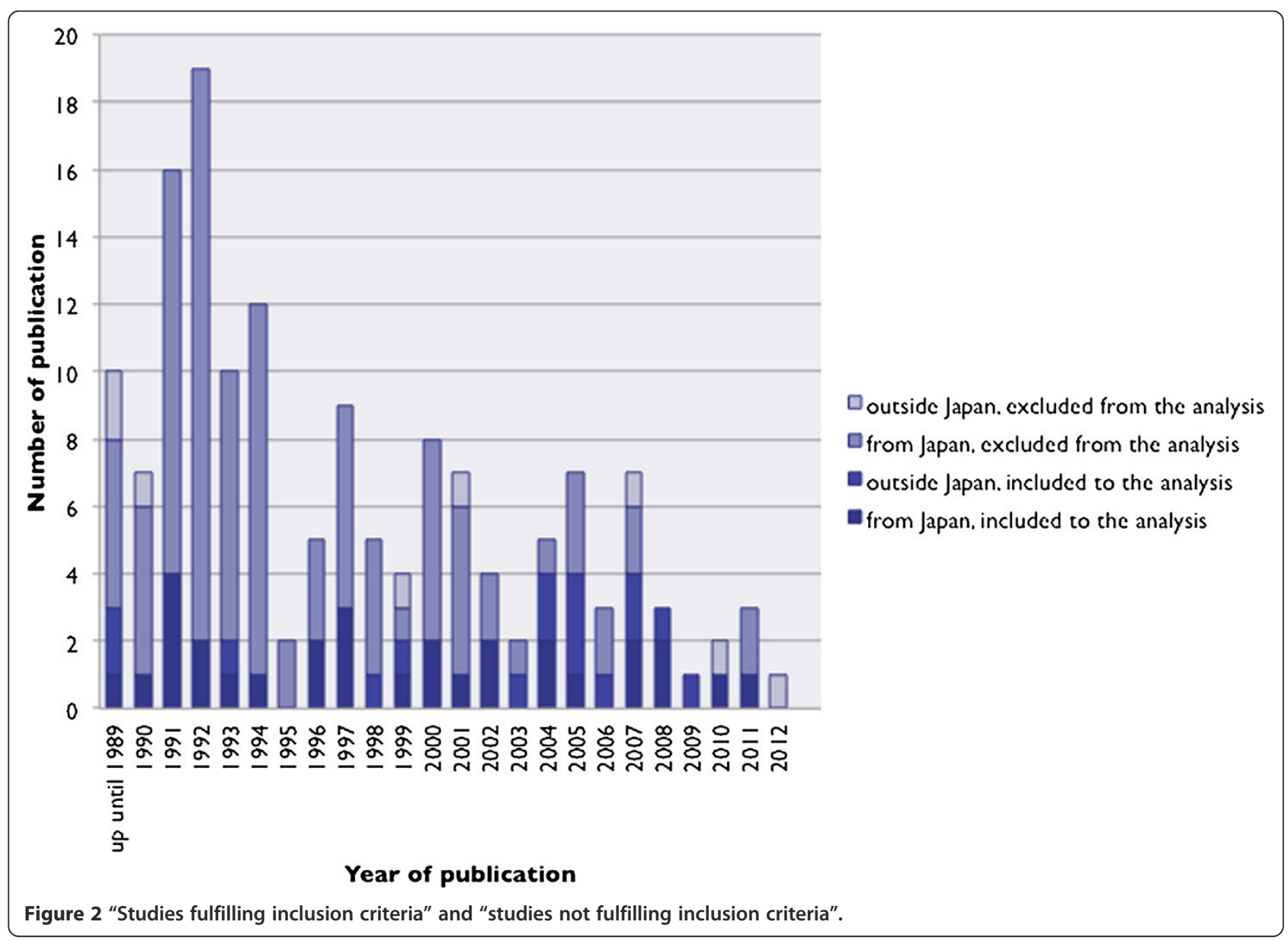


positive cocci in cluster, 4) stool samples demonstrating the presence of MRSA, while excluding other pathogens such as Clostridium difficile, 5) comparison with healthy subjects (modified to accommodate comparisons with patients with $\mathrm{CDI}$ ), 6) toxin assay to identify potential/ plausible toxin(s), which is/are found in case but not in control, 7) animal models, with histologic, microbiological evidence of AAE caused by MRSA. We also added that; 8) patient's condition improves after the use of antiMRSA agents [7], since it will strengthen the likelihood of MRSA being the causative agent, unlike AAE caused by $K$. oxytoca, which does not require specific treatment if the causative antibiotic was discontinued. We also excluded cases of toxic shock syndrome (TSS) and food poisoning (Criterion 9). Although diarrhea is often observed in TSS caused by Staphylococcus aureus, we considered TSS a different entity from antibiotic-associated enterocolitis. Similarly, we tried to distinguish reports of diarrhea, suspected to be caused by food poisoning, which is a wellknown self-limiting disease caused by $S$. aureus but not to be confused with antibiotic-associated enterocolitis-which often requires specific antibiotic treatment.

We considered the use of selective, anaerobic stool cultures for $C$. difficile as the ideal method to exclude
CDI since it is the most sensitive [16,17]. Absence of $C$. difficile by conventional stool culture was not considered sufficient to exclude CDI, since it has a low sensitivity. Although the $C$. difficile toxin assay is frequently used for the diagnosis of CDI in clinical settings, it lacks the sensitivity to exclude CDI [16]. Therefore, we considered the use of toxin assays as "moderate" evidence for exclusion of CDI, and reports describing the use of these assays were discussed accordingly. The stool glutamate dehydrogenase assay (GDH), a commonly used assay for the diagnosis of CDI, has relatively high negative predictive value $[18,19]$, and we considered that negative GDH results could serve as moderate evidence for exclusion of CDI. Until the late 2000's, stool assays for both toxin $\mathrm{A}(\mathrm{Tcd} \mathrm{A})$ and $\mathrm{B}(\mathrm{TcdB})$ were not available in Japan, and the presence of TcdA only had been examined [20]. Since about $6 \%$ of $C$. difficile are non-TcdA producing/TcdB producing $(\mathrm{A}-/ \mathrm{B}+)$, this was also taken into consideration [20].

Conventional stool cultures often fail to identify C. difficile and exposure to antibiotics may leave MRSA as the only identifiable pathogen. Therefore, we excluded studies merely finding MRSA in stool culture without specifically attempting to exclude CDI.

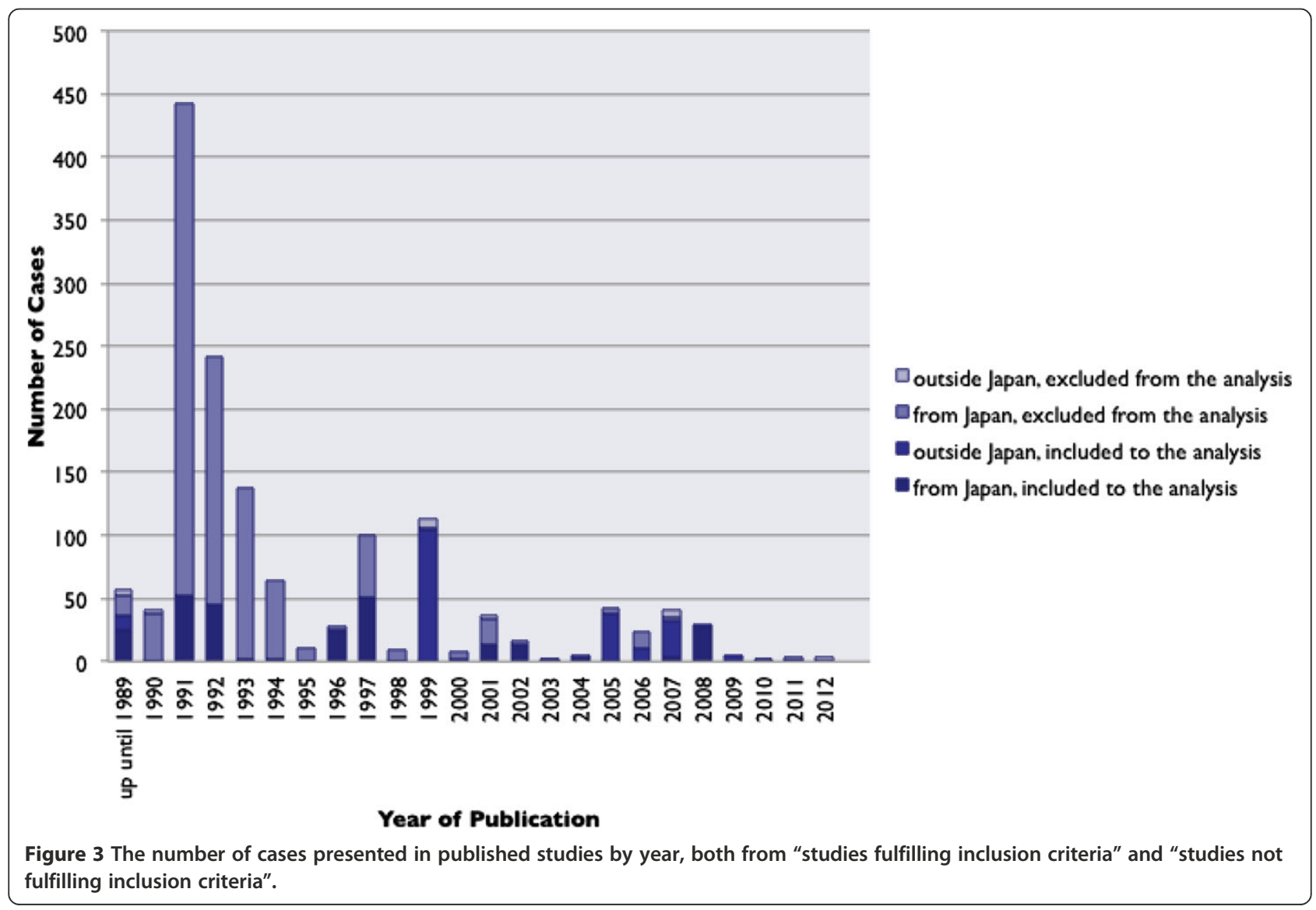


Table 1 Summary of Case Records and Case Series on Antibiotic Associated Enterocolitis considered to be caused by MRSA

\begin{tabular}{|c|c|c|c|c|c|c|c|c|c|c|c|c|}
\hline Reference & Year & Country & $\begin{array}{c}\text { No. of } \\
\text { patients }\end{array}$ & $\begin{array}{c}\text { Prior } \\
\text { exposure } \\
\text { to } \\
\text { antibiotics }\end{array}$ & $\begin{array}{l}\text { Endoscopic findings } \\
\text { c/w AAE }\end{array}$ & $\begin{array}{l}\text { Gram staining or } \\
\text { other microscopic } \\
\text { findings }\end{array}$ & $\begin{array}{l}\text { Presence of } \\
\text { MRSA while } \\
\text { excluding CDI }\end{array}$ & $\begin{array}{c}\text { Comparison } \\
\text { group }\end{array}$ & Toxin assay & $\begin{array}{c}\text { Animal } \\
\text { model }\end{array}$ & $\begin{array}{l}\text { Response to } \\
\text { the treatment }\end{array}$ & $\begin{array}{l}\text { Judged to be } \\
\text { different from } \\
\text { TSS or food } \\
\text { poisoning }\end{array}$ \\
\hline $\begin{array}{l}\text { Hori et al. } \\
\text { [8]. }\end{array}$ & 1989 & Japan & 154 & Some $e^{c}$ & No & No & Some $^{d}$ & No & $\begin{array}{l}\text { Yes (SEC, } \\
\text { and TSST-1) }\end{array}$ & No & Yes & Some TSSs \\
\hline $\begin{array}{l}\text { McDonald } \\
\text { et al. [23]. }\end{array}$ & 1982 & Australia & 10 & Yes & Yes in $1 \mathrm{pt}$ & Yes & $\begin{array}{c}\text { Yes by CCFA cx } \\
\text { and TA }\end{array}$ & No & No & No & Yes & Yes \\
\hline $\begin{array}{l}\text { Christie } \\
\text { et al. [24]. }\end{array}$ & 1988 & USA & 1 & No & No & No & Yes by $T A^{a}$ & Yes & Yes $^{\mathrm{b}}$ & No & Yes & Yes \\
\hline $\begin{array}{l}\text { Sakamoto } \\
\text { et al. [25]. }\end{array}$ & 1990 & Japan & 1 & Yes & Yes & No & Yes by TA & No & $\begin{array}{l}\text { Negative } \\
\text { TSST-1 }\end{array}$ & No & Yes & Yes \\
\hline $\begin{array}{l}\text { Matsuo } \\
\text { et al. [26]. }\end{array}$ & 1991 & Japan & 34 & Yes in 28 & $\begin{array}{l}4 \text { patients with autopsy } \\
\text { findings }\end{array}$ & No & Yes by CCFA cx. & No & No & No & Yes & No \\
\hline $\begin{array}{l}\text { Nakashio } \\
\text { et al. [27]. }\end{array}$ & 1991 & Japan & 1 & No & No & No & Yes $^{d}$ & No & $\begin{array}{l}\text { Yes (SEC and } \\
\text { TSST-1) }\end{array}$ & No & No & Probably TSS ${ }^{f}$ \\
\hline $\begin{array}{l}\text { Takeshima } \\
\text { et al. [28]. }\end{array}$ & 1991 & Japan & 16 & Yes & No & No & Yes by CCMA cX. & No & No & No & No & Yes \\
\hline $\begin{array}{l}\text { Ueda et al. } \\
\text { [29]. }\end{array}$ & 1991 & Japan & 2 & Yes & No & No & $\begin{array}{l}\text { Yes by GDH and } \\
\text { cx of unknown } \\
\text { methods. }\end{array}$ & No & $\begin{array}{l}\text { Yes (SEA and } \\
\text { TSST-1) }\end{array}$ & No & Yes & UC \\
\hline $\begin{array}{l}\text { Hanatani } \\
\text { et al. [30]. }\end{array}$ & 1992 & Japan & 1 & Yes & No & Yes & Yes by TA & No & $\begin{array}{l}\text { Yes (TSST-1 } \\
\text { coding } \\
\text { gene) }\end{array}$ & No & Yes & Yes \\
\hline $\begin{array}{l}\text { Inamatsu } \\
\text { et al. [31]. }\end{array}$ & 1992 & Japan & 32 & Yes & No & No & $\begin{array}{l}\text { Yes by TA and } \\
\text { cx of unknown } \\
\text { methods. }\end{array}$ & No & $\begin{array}{l}\text { Yes (SE and } \\
\text { TSST-1) }\end{array}$ & No & Yes & $\begin{array}{l}\text { One pt might } \\
\text { have had TSS }\end{array}$ \\
\hline $\begin{array}{l}\text { Masuda } \\
\text { et al. [32]. }\end{array}$ & 1993 & Japan & 1 & Yes & No & Yes & Yes by GDH & No & No & No & Yes & Yes \\
\hline $\begin{array}{l}\text { Taylor et al. } \\
\text { [33]. }\end{array}$ & 1993 & UK & 1 & Yes & No & No & $\begin{array}{l}\text { Yes by TA and } \\
\text { cx of unknown } \\
\text { methods. }\end{array}$ & No & Yes (SEA) & No & Yes & Yes \\
\hline $\begin{array}{l}\text { Takatera } \\
\text { et al. [34]. }\end{array}$ & 1994 & Japan & 2 & Yes & No & No & Yes by GDH & No & No & No & Yes & Yes \\
\hline $\begin{array}{l}\text { Kuramoto } \\
\text { et al. [35]. }\end{array}$ & 1996 & Japan & 16 & Yes & No & No & Yes by TA & Yes & No & No & Yes & Yes \\
\hline $\begin{array}{l}\text { Watanabe } \\
\text { et al. [36]. }\end{array}$ & 1996 & Japan & 9 & Yes & No & No & $\begin{array}{l}\text { Yes by GDH and } \\
\text { cx of unknown } \\
\text { methods. }\end{array}$ & Yes & No & No & Yes & Yes \\
\hline
\end{tabular}


Table 1 Summary of Case Records and Case Series on Antibiotic Associated Enterocolitis considered to be caused by MRSA (Continued)

\begin{tabular}{|c|c|c|c|c|c|c|c|c|c|c|c|c|}
\hline $\begin{array}{l}\text { Konishi } \\
\text { et al. [37]. }\end{array}$ & 1997 & Japan & 31 & Probably $^{9}$ & No & No & $\begin{array}{l}\text { Yes by } c x \text { of } \\
\text { unknown } \\
\text { methods. }\end{array}$ & No & No & No & Yes & Yes \\
\hline $\begin{array}{l}\text { Sakai et al. } \\
\text { [38]. }\end{array}$ & 1997 & Japan & 19 & Yes & No & No & $\begin{array}{l}\text { Yes by GDH and } \\
\text { cx of unknown } \\
\text { methods. }\end{array}$ & $\begin{array}{l}\text { Compared } \\
\text { with CDI }\end{array}$ & No & No & No & Yes \\
\hline $\begin{array}{l}\text { Yoshida } \\
\text { et al. [39]. }\end{array}$ & 1997 & Japan & 1 & Yes & $\begin{array}{l}\text { Autopsy findings } \mathrm{c} / \mathrm{w} \\
\text { multiple ulcers with } \\
\text { abscess. No } \\
\text { pseudomembrane } \\
\text { formation. }\end{array}$ & Yes & $\begin{array}{l}\text { Yes by unknown } \\
\text { methods. }\end{array}$ & No & Yes (SEC) & No & No & Yes \\
\hline $\begin{array}{l}\text { Schiller et al. } \\
\text { [40]. }\end{array}$ & 1998 & USA & 1 & Yes & No & Yes & Yes by TA & No & No & No & $\begin{array}{l}\text { Yes with } \\
\text { ineffectiveness } \\
\text { of } \\
\text { metronidazole. }\end{array}$ & Yes \\
\hline $\begin{array}{l}\text { Kimata et al. } \\
\text { [22]. }\end{array}$ & 1999 & Japan & 1 & No & No & No & Yes by GDH & No & $\begin{array}{l}\text { Yes (SEC, } \\
\text { TSST-1, and } \\
\text { protease B) }\end{array}$ & No & Yes & Yes \\
\hline $\begin{array}{l}\text { Gravet et al. } \\
\text { [41]. }\end{array}$ & 1999 & France & 104 & Yes & No & No & $\begin{array}{l}\text { Yes by CCFA } \\
\text { and TA }\end{array}$ & Yes $^{h}$ & $\begin{array}{l}\text { Yes (SEA, } \\
\text { SED, LukE- } \\
\text { LukD') }\end{array}$ & No & Yes & Yes \\
\hline $\begin{array}{l}\text { Terada et al. } \\
\text { [42]. }\end{array}$ & 2000 & Japan & 1 & No & No & No & Yes by TA & No & Yes (TSST-1) & No & Yes & Yes \\
\hline $\begin{array}{l}\text { Watanabe } \\
\text { et alj [43]. }\end{array}$ & 2001 & Japan & 13 & Yes & No & No & $\begin{array}{l}\text { Yes by GDH and } \\
\text { cx of unknown } \\
\text { methods. }\end{array}$ & No & $\begin{array}{l}\text { Yes (SEA, } \\
\text { SEC and } \\
\text { TSST-1) }\end{array}$ & No & No & Yes \\
\hline $\begin{array}{l}\text { Yanagi et al. } \\
\text { [44]. }\end{array}$ & 2002 & Japan & 1 & Yes & No & No & Yes by GDH & No & $\begin{array}{l}\text { Yes (SEC and } \\
\text { TSST-1) }\end{array}$ & No & Yes & No \\
\hline $\begin{array}{l}\text { Igami et al. } \\
\text { [45]. }\end{array}$ & 2002 & Japan & 13 & Yes & No & No & Yes by GDH & No & No & No & Yes & Yes \\
\hline $\begin{array}{l}\text { Lee et al. } \\
\text { [46]. }\end{array}$ & 2003 & S. Korea & 1 & Yes & Yes & Yes & Yes by TA & No & No & No & Yes & Yes \\
\hline $\begin{array}{l}\text { Fujita et al. } \\
{[47] .}\end{array}$ & 2004 & Japan & 1 & Yes & $\begin{array}{c}\text { Autopsy findings } \mathrm{C} / \mathrm{W} \text { PC } \\
\text { with cocci }\end{array}$ & Yes & Yes by GDH & No & No & No & No & $\mathrm{No}^{\mathrm{k}}$ \\
\hline $\begin{array}{l}\text { Yoshida } \\
\text { et al. [48]. }\end{array}$ & 2004 & Japan & 1 & Yes & Yes & No & Yes by TA & No & No & No & No & $\begin{array}{l}\text { Probably } \\
\text { necrotizing } \\
\text { enterocolitis with } \\
\text { Fournier } \\
\text { gangrene. }\end{array}$ \\
\hline
\end{tabular}

No

Yes 
Table 1 Summary of Case Records and Case Series on Antibiotic Associated Enterocolitis considered to be caused by MRSA (Continued)

\begin{tabular}{|c|c|c|c|c|c|c|c|c|c|c|c|c|}
\hline $\begin{array}{l}\text { Froberg } \\
\text { et al. [49]. }\end{array}$ & & & & & & $\begin{array}{l}\text { Yes. Also, PCR of } \\
\text { pseudomembrane } \\
\text { was positive for } \\
\text { MRSA. }\end{array}$ & & & & & & \\
\hline $\begin{array}{l}\text { Rhee et al. } \\
\text { [50]. }\end{array}$ & 2004 & USA & 1 & Yes & No & No & Yes by TA & No & No & No & $\begin{array}{l}\text { Yes (and no } \\
\text { response to } \\
\text { metronidazole) }\end{array}$ & Yes \\
\hline $\begin{array}{l}\text { Nishizawa } \\
\text { et al. [51]. }\end{array}$ & 2005 & Japan & 1 & Yes & No & No & Yes by GDH & No & No & No & Yes & No \\
\hline $\begin{array}{l}\text { Ackermann } \\
\text { et al' [52]. }\end{array}$ & 2005 & Germany & 25 & Yes & No & No & $\begin{array}{c}\text { Yes by CCFA cx } \\
\text { and TA. }\end{array}$ & $\begin{array}{l}\text { Compared } \\
\text { with CDI. }\end{array}$ & $\begin{array}{l}\text { Yes (SEA, } \\
\text { SEB, SEC, } \\
\text { and SED) }\end{array}$ & No & UC & No \\
\hline $\begin{array}{l}\text { McPherson } \\
\text { et al. [53]. }\end{array}$ & 2005 & UK & 1 & Yes & No & No & Yes by TA & No & No & No & Yes & Yes \\
\hline $\begin{array}{l}\text { Boyce et al. } \\
\text { [54]. }\end{array}$ & 2005 & USA & 11 & Yes & & & Yes by CCFA cx & Yes & $\begin{array}{l}\text { Yes (SEA, } \\
\text { SEB, and } \\
\text { SED) }\end{array}$ & No & Yes & Yes \\
\hline $\begin{array}{l}\text { Asha et al. } \\
\text { [55]. }\end{array}$ & 2006 & UK & 10 & Yes & No & No & $\begin{array}{c}\text { Yes by CCEY cx } \\
\text { and TA. }\end{array}$ & $\begin{array}{c}\text { Compared } \\
\text { with CDI and } \\
\text { C. perfringens } \\
\text { infections. }\end{array}$ & $\begin{array}{l}\text { Yes (SEA, } \\
\text { SEC, SED } \\
\text { and TSST-1) }\end{array}$ & No & UK & Yes \\
\hline $\begin{array}{l}\text { Kurabayashi } \\
\text { et al. [56]. }\end{array}$ & 2007 & Japan & 1 & Yes & No & Yes & Yes by GDH & No & No & No & Yes & Yes \\
\hline $\begin{array}{l}\text { Nagao et al. } \\
\text { [57]. }\end{array}$ & 2007 & Japan & 2 & Yes & No & No & $\begin{array}{l}\text { positive TA (A } \\
\text { only) in cone } \\
\text { case. Negative } \\
\text { in the other. }\end{array}$ & No & No & No & $\begin{array}{l}\text { Yes, and no } \\
\text { response to } \\
\text { metronidazole. }\end{array}$ & Yes \\
\hline $\begin{array}{l}\text { Flemming } \\
\text { et al. [58]. }\end{array}$ & 2007 & Germany & 29 & Yes & No & No & $\begin{array}{c}\text { Yes by CCFA cx } \\
\text { and TA }\end{array}$ & With CDI. & $\begin{array}{l}\text { Yes (SEA, } \\
\text { SEB, SEC, } \\
\text { SED, and } \\
\text { SEE) }\end{array}$ & No & UC & Yes \\
\hline $\begin{array}{l}\text { Kotler et al. } \\
\text { [59]. }\end{array}$ & 2007 & USA & 1 & No & Yes & $\begin{array}{l}\text { Yes (Gram stain of } \\
\text { ileal tissue and } \\
\text { transmission } \\
\text { electron } \\
\text { micrograph) }\end{array}$ & Yes by TA & No & $\begin{array}{l}\text { Yes (SEB, } \\
\text { SEC) }\end{array}$ & No & Yes & $\begin{array}{l}\text { Co-existence of } \\
\text { TSS and } \\
\text { enterocolitis. }\end{array}$ \\
\hline $\begin{array}{l}\text { Shiraishi } \\
\text { et al. [60]. }\end{array}$ & 2008 & Japan & 18 & UC & No & No & Yes by TA & With CDI & No & No & Yes & Yes \\
\hline \multirow{2}{*}{$\begin{array}{l}\text { Tamura } \\
\text { et al. [61]. }\end{array}$} & 2008 & Japan & 10 & Yes & No & No & Yes by GDH & With CDI & No & No & Yes & Yes \\
\hline & 2008 & USA & 2 & Yes & No & Yes & Yes by TA & No & No & No & Yes & Yes \\
\hline
\end{tabular}


Table 1 Summary of Case Records and Case Series on Antibiotic Associated Enterocolitis considered to be caused by MRSA (Continued)

\begin{tabular}{|c|c|c|c|c|c|c|c|c|c|c|c|c|}
\hline \multicolumn{13}{|l|}{$\begin{array}{l}\text { Dalal et al. } \\
\text { [62]. }\end{array}$} \\
\hline $\begin{array}{l}\text { Lo et al. } \\
\text { [63]. }\end{array}$ & 2009 & USA & 5 & Yes & No & No & Yes by TA & No & No & No & Yes & Yes \\
\hline $\begin{array}{l}\text { Fujii et al. } \\
\text { [64]. }\end{array}$ & 2010 & Japan & 1 & UC & No & No & Yes by TA & No & No & No & Yes & Yes \\
\hline $\begin{array}{l}\text { Kitahata Y } \\
\text { et al. [65]. }\end{array}$ & 2011 & Japan & 1 & Yes & Yes & No & Yes by GDH & No & No & No & Yes & Yes \\
\hline
\end{tabular}

Abbreviations: MRSA methicillin-resistant Staphylococcus aureus, C/w consistent with, AAE antibiotic associated enterocolitis, CDI Clostridium difficile infection, TSS toxic shock syndrome, pt patient, CCFA cycloserinecefoxitin-fructose agar, $C X$ culture, TA toxin assay, SEC staphylococcal enterotoxin C, TSST-1 toxic shock syndrome toxin-1, CCMA cycloserine-cefoxitin-mannitol ager, GDH glutamate dehydrogenase assay, SEA staphylococcal enterotoxin A, SE staphylococcal enterotoxins, SED staphylococcal enterotoxin D, SEB staphylococcal enterotoxin B, UC unclear, PC pseudomembranous colitis, CCEY cycloserine-cefoxitin egg yolk agar, SEE staphylococcal enterotoxin

a. There was no specification whether S. aureus in this article was indeed MRSA. However, the patient was treated with oral vancomycin, suggesting it was.

b. Cytopathic effects (CPE) were seen both via intracellular growth of $S$. aureus and with cell-free supernatant, suggesting the presence of toxin in $S$. aureus from the case. CPEs were not seen both in control S. aureus and its supernatant.

c. Among the patients identified, the analysis was done for the use of antibiotics in 30 cases.

d. The article did refer to $C$. difficile but did not specify the methods to identify it.

e. Seventeen out of 34 patients did have concurrent C. difficile infection.

f. The patient developed septic shock with multiple organ failure, with identification of MRSA from multiple sites.

g. All cases are postoperative. Although there was no specific reference on the use of antibiotics, most patients in Japan usually receive varieties of antibiotics routinely after surgery, particularly in 1980s and 90 s. h. Randomly selected S. aureus isolates were used for comparison of toxin productions.

i. LukE-LukD are one of staphylococcal leukotoxin family [66].

j. It is possible that some patients in this paper might been described in reference 37 in duplicates.

$k$. The patient died of shock and organ failure. The blood culture after the death grew MRSA.

I. All isolates of $S$. aureus in this study was oxacillin susceptible. 
Table 2 Summary of the fulfillment of proposed diagnostic criteria of AAE by MRSA

\begin{tabular}{|c|c|c|c|c|c|c|c|c|c|}
\hline Criterion \# & $\begin{array}{c}\text { Criterion } \\
1\end{array}$ & $\begin{array}{c}\text { Criterion } \\
2\end{array}$ & $\begin{array}{c}\text { Criterion } \\
3\end{array}$ & $\begin{array}{c}\text { Criterion } \\
4\end{array}$ & $\begin{array}{c}\text { Criterion } \\
5\end{array}$ & $\begin{array}{c}\text { Criterion } \\
6\end{array}$ & $\begin{array}{c}\text { Criterion } \\
7\end{array}$ & $\begin{array}{c}\text { Criterion } \\
8\end{array}$ & $\begin{array}{c}\text { Criterion } \\
9\end{array}$ \\
\hline Criterion & $\begin{array}{c}\text { Prior } \\
\text { exposure } \\
\text { to } \\
\text { antibiotics }\end{array}$ & $\begin{array}{c}\text { Endoscopic } \\
\text { findings c/ } \\
\text { w AAE }\end{array}$ & $\begin{array}{l}\text { Gram staining } \\
\text { or other } \\
\text { microscopic } \\
\text { findings }\end{array}$ & $\begin{array}{c}\text { Presence of } \\
\text { MRSA while } \\
\text { excluding } \\
\text { CDI }\end{array}$ & $\begin{array}{c}\text { Comparison } \\
\text { group }\end{array}$ & $\begin{array}{l}\text { Toxin } \\
\text { assay }\end{array}$ & $\begin{array}{l}\text { Animal } \\
\text { model }\end{array}$ & $\begin{array}{l}\text { Response } \\
\text { to the } \\
\text { treatment }\end{array}$ & $\begin{array}{l}\text { Judged to be } \\
\text { different from } \\
\text { TSS or food } \\
\text { poisoning }\end{array}$ \\
\hline $\begin{array}{l}\text { Number of } \\
\text { studies } \\
\text { fulfilled the } \\
\text { criterion }\end{array}$ & 38 & 10 & 11 & 45 & 11 & 18 & 0 & 34 & 34 \\
\hline
\end{tabular}

Abbreviations: MRSA methicillin-resistant Staphylococcus aureus, c/w consistent with, AAE antibiotic associated enterocolitis, CDI Clostridium difficile infection, TSS toxic shock syndrome.

\section{Results}

\section{Literature review}

The electronic search identified 2,315 titles (265 from Pubmed, 1,326 from Embase, 0 from the Cochrane library, and 724 from the Japan Medical Abstract Society database). All titles and abstracts were granted full review (Figure 1).

\section{Evaluation of included cases}

A total of 152 case reports or case series on a combined total of 1,463 patients were deemed relevant as a result of the initial literature search. The number of articles reporting MRSA enterocolitis has declined over the years (Figure 2), and with that the number of reported cases (Figure 3). Among the selected articles, 31 articles were written in English, one was in Korean, and the remaining 120 articles were written in Japanese. Onehundred-twenty-four articles were from Japan (124/152, 81.6\%). Within the 152 articles reviewed, 106 (106/152, $69.1 \%$ ) were excluded on the basis that they simply diagnosed MRSA enterocolitis based on stool cultures, without making reference to any attempts to exclude CDI. One article written in Japanese [21] was judged to be a duplicate of another case report published in English [22] and therefore the former was removed from the analysis. The remaining 45 articles were reviewed for the pathogenicity of AAE caused by MRSA (Figure 1, and Table 1).

Among these 45 articles, no single study fulfilled all 9 of the criteria we proposed (Table 2). The maximum number of criteria fulfilled by a single study was 6 criteria (6 studies), and the minimum was 2 (one study). Only 8 studies utilized selective culture media for excluding CDI [23,26,28,41,52,54,55,58] and it should be further noted that one of the articles described AAE due to methicillin-sensitive $S$. aureus [52]. There was no animal study accompanying clinical data. Three studies demonstrated the presence of cocci in pathological specimens, which strongly suggested MRSA as being the cause of enterocolitis [47,49,59]. Froberg et al. also detected genes uniquely expressed in MRSA ( $\operatorname{mec} A)$ in the pseudomembrane [49]. Comparison with either stools from healthy subjects, $[24,35,36,41,54]$ or clinical features with CDIs [38,52,55,58,60,61] were made in 11 studies. Eighteen studies provided data on toxin production, such as enterotoxins, toxic shock syndrome toxin-1 (TSST-1), protease B, and leucotoxins (LukE-LukD). In one study, the cytopathic effects (CPE) were observed via both intracellular growth of $S$. aureus and with cellfree supernatant, suggesting the presence of toxin in $S$. aureus in the cases presented. CPEs were not observed in either control S. aureus or its supernatant [24].

\section{Basic studies including studies utilizing animal models}

Basic studies including those using animal experiments were also sought for analyses. We were able to retrieve 9 potential articles, which appeared relevant.

The oldest article we could retrieve was by van Prohaska [67]. He introduced $S$. aureus, isolated from patients with pseudomembranous enterocolitis or from food implicated in human food poisoning, along with its enterotoxins to chinchillas and cats and reproduced pseudomembranous colitis, as confirmed by necropsy [67]. Although he was able to demonstrate that S. aureus and its enterotoxin could cause pseudomembranous enterocolitis in chinchillas, it is unlikely that MRSA or AAE was the cause. Kawai used a rat model with or without gastrectomy and introduced MRSA obtained from patients with diarrhea (positive SEC, TSST-1) after administering kanamycin and metronidazole. The same study confirmed that MRSA multiplied in the rat intestine but failed to demonstrate the occurrence of enterocolitis [68]. Likewise, one study used a mouse model, and showed that the use of ampicillin improved the colonization of MRSA in the intestines. The same study, however, did not directly examine the pathogenesis of MRSA as the cause of enterocolitis [69]. Similar studies reporting strikingly similar results were conducted by different groups using mice [70], and rats [71]. Arima used a rat model by introducing MRSA from a patient with postoperative MRSA enterocolitis who had been administered kanamycin and metronidazole. MRSA colonized in rat intestines, and after administrating latamoxef (oxacephem antibiotic) and cyclophosphamide, 
MRSA growth significantly increased, which ended in bacteremia and metastatic infections to the liver, kidneys, and spleen [72]. Again, this paper also failed to confirm the occurrence of enterocolitis induced by antibiotic treatment.

Nakamura et al. also reported a study using a mouse model. After injecting cyclophosphamide and inducing an immunocompromised state in mice, the group introduced MRSA from patients with postoperative enterocolitis into the jejunum of the mice. After injecting ampicillin and moxalactam for 5 days, they succeeded in producing severe diarrhea in mice, with histologically confirmed inflammation in the jejunum [73]. Although the experiment was rather artificial and the jejunum is not a typical location for AAE, this study was the firstto our knowledge-to histologically describe AAE caused by MRSA in an animal model. A similar form of regional enteritis was demonstrated by others practicing the same method $[74,75]$.

\section{Discussion}

Staphylococcal enterocolitis was first reported in 1942 in an epidemic in a maternity unit [76]. Staphylococcal enterocolitis in association with the administration of antibiotics was first reported in 1948 [77]. Since then, cases of AAE caused by $S$. aureus continued to be reported $[67,78,79]$ and by the end of the 1950s, S. aureus was considered to be one of the major causes of AAE [80].

However, since Clostridium difficile and its toxin were found to be associated with antibiotic-associated pseudomembranous colitis [2-5], the significance of $S$. aureus was all but marginalized. John G. Bartlett, one of the world's most well-known infectious diseases specialists and one of the discoverers of $C$. difficile as the cause of pseudomembranous colitis, stated that, "Staph. aureus was implicated as the chief cause of antibiotic-associated pseudomembranous enterocolitis in the 1950s. It is unclear whether this finding represented misdiagnosis of $C$. difficile infection or Staph. aureus caused a different disease" [1], implying that AAE by S. aureus might not exist, but instead CDI with positive MRSA cultures could have been misinterpreted as AAE by MRSA. Subsequently, routine stool cultures in the hospital setting were discontinued in the United States [81], and physicians virtually ceased to seek out $S$. aureus as a cause of AAE. Only the C. difficile toxin assay became the method for diagnosing AAE [16]. The world's leading textbooks on both Internal Medicine and Infectious Diseases no longer refer to $S$. aureus as a cause of AAE [82,83]. UpToDate and DynaMed, both popular electronic clinical resources, do not lead to sections related to MRSA enterocolitis by using keywords such as "antibiotic associated diarrhea," or "staphylococcus aureus" (as of May 23, 2013). The Infectious Diseases Society of America, or IDSA, guidelines published on MRSA also has no mention of enterocolitis associated with this particular pathogen [84].

In contrast, numerous articles on MRSA enterocolitis have been published from Japan since the late 1980's, as shown in our systematic review. Most were written in the Japanese language and consequently went largely unnoticed overseas. To add to the dilemma, most studies published in Japan failed to exclude CDI from the differential. Many failed to make any attempt at searching for C. difficile and some used less sensitive tests, such as $\mathrm{GDH}$ assays as exclusion criteria for CDI. A C. difficile toxin assay for both $\mathrm{CdtA}$ and $\mathrm{CdtB}$ was approved in 2007 in Japan [20,85], however, prior to this assays for only CdtA had been used, and many studies claiming to have excluded CDI by toxin assay might have failed to detect CDI producing only CdtB. Furthermore, metronidazole was not approved for the treatment of CDI until 2012 in Japan [12], and oral vancomycin was the only antibiotic used for the treatment of AAE. Consistent with Bartnett's implication, this may have resulted in confusion, which erroneously lead physicians to believe that they were treating MRSA enterocolitis. The lack of similar reports abroad, as well as the lack of studies with scientific rigor cultivated a sense of skepticism to spread amongst Japanese physicians. To add fuel to this skepticism, articles regarding AAE by MRSA, even from Japan, have declined in recent years.

But does this mean that AAE caused by MRSA simply does not exist, and that the apparent epidemic in Japan can be traced to mere ill-definition?

Our answer, based on this systemic review is both "yes" and "no." While largely ignored in many countries such as the United States, the current systematic review suggests AAE by MRSA most likely exists. Likewise, the majority of cases reported from Japan were probably not AAE by MRSA, and many of these cases were simply a misdiagnosis of CDI (with occasionally different causative entities such as TSS).

In more recent years, experts in both Europe and the USA have rekindled their interests in S. aureus as a potential cause for AAE [62,86-88]. It is also important to note that other pathogens such as Klebsiella oxytoca have also been found to cause AAE [15].

Our investigation ultimately failed to show any single study on AAE caused by MRSA matching the scientific rigor embodied in the report published by Högenauer et al. for the diagnosis of AAE by $K$. oxytoca, which collected clinical cases, examined cytotoxin produced by $K$. oxytoca, compared stool samples with that from healthy subjects, and even established an in vivo animal model [15]. However, our systematic review could fulfill all of the established criteria by collectively analyzing data from multiple studies. We found clinical cases of enterocolitis associated with antibiotic use. Studies demonstrated the 
existence of MRSA in patients, while excluding CDI with sensitive culture media. There was histopathological confirmation on the presence of Gram positive cocci in lesions with inflammation from patients with AAE, which makes the argument for misinterpretation of CDI very unlikely. Comparisons with stool from healthy subjects were conducted, production of toxins was demonstrated, and animal models were established. Even though MRSA enterocolitis associated with antibiotic use may not be all that common-which is in stark contrast to what Japanese physicians had believed until recently-it probably does exist to some extent.

Our review has several inherent limitations. First, we may not have been able to identify all relevant studies, although the independent selection of studies, including those written in non-English language from the Japan Medical Abstract Society database, by two independent reviewers suggests adequate identification among published literatures. Likewise, we did not search for unpublished literatures, which could have relevance to our study. Second, although we were able to fulfill the criteria for the presence of AAE caused by MRSA collectively, no single study independently did so, which slightly weakens the validity of our hypothesis. Third, even if AAE caused by MRSA truly exists, we were unable to demonstrate its clinical significance, including its incidence, clinical characteristics, risk factors, economic impacts, and its consequence such as mortality. Flemming et al. identified MRSA in 29 out of 2,727 stool samples (1.1\%) of nosocomial diarrhea [58], implying that AAE caused by MRSA is relatively rare, but not extremely uncommon. However, it is well known that the prevalence of MRSA differs significantly from one country to the other [89], and elucidation of the exact incidence of AAE by MRSA warrants independent investigation in each geographical region or country. These clinically relevant agendas should be evaluated in future studies.

\section{Conclusions}

Even though many cases reported mainly from Japan by themselves failed to verify the existence of Antibiotic Associated Enterocolitis caused by MRSA, our systematic review suggests it does probably exist.

\section{Competing interests}

No external source of funding played a role in the study design, implementation, analysis, manuscript preparation, or decision to submit the manuscript for publication. The authors declare that they have no competing interests.

\section{Authors' contributions}

$\mathrm{KI}, \mathrm{DA}, \mathrm{GO}$, and HK participated in the design of the study. KI, DA, TF, YS, and TS conducted data collection and initial analyses. $\mathrm{KI}$ and DA conducted indepth analyses of selected studies. KI prepared the draft of the manuscript. $\mathrm{KI}$ and TF prepared the figures. All participated in the revision of the manuscript, read and approved the final manuscript.

\section{Acknowledgements}

We are indebted to Dr. Richard H. Kaszynski for the correction of English of the manuscript. Dr. Kaszynski also does not have any competing interests.

\section{Author details}

'Division of Infectious Disease, Kobe University Hospital, 7-5-2 Kusunokicho, Chuoku, 650-0017 Kobe, Hyogo, Japan. ${ }^{2}$ Division of Infectious Diseases, Kobe City Medical Center General Hospital, 2-1-1 Minamicho, Mintojima, Chuoku, 650-0047 Kobe, Hyogo, Japan. ${ }^{3}$ Department of Pediatrics, Himeji Red Cross Hospital, 1-12-1 Shimoteno, 670-0063 Himeji, Hyogo, Japan. ${ }^{4}$ Department of Radiology, Kobe University Hospital, 7-5-2 Kusunokicho, Chuoku, 650-0017 Kobe, Hyogo, Japan. ${ }^{5}$ Division of Infectious Diseases, Shinko Hospital, 1-4-47 Wakihamacho, Chuoku, 651-0072 Kobe, Hyogo, Japan.

Received: 24 November 2013 Accepted: 6 May 2014 Published: 9 May 2014

\section{References}

1. Bartlett JG: Antibiotic-associated diarrhea. N Engl J Med 2002, 346:334-339.

2. Kotler DP, Sordillo EM: A case of Staphylococcus aureus Enterocolitis: a rare entity. Gastroenterol Hepatol 2010, 6:117-9.

3. Bartlett JG, Chang TW, Gurwith M, Gorbach SL, Onderdonk AB: Antibioticassociated pseudomembranous colitis due to toxin-producing clostridia. N Engl J Med 1978, 298:531-4.

4. Larson HE, Price AB, Honour P, Borriello SP: Clostridium difficile and the aetiology of pseudomembranous colitis. Lancet 1978, 1:1063-6.

5. Bartlett JG, Willey SH, Chang TW, Lowe B: Cephalosporin-Associated Pseudomembranous Colitis due to Clostridium difficile. JAMA 1979, 242:2683-5.

6. Högenauer C, Hammer HF, Krejs GJ, Reisinger EC: Mechanisms and management of antibiotic-associated diarrhea. Clin Infect Dis 1998, 27:702-10.

7. Beaugerie L, Petit J-C: Microbial-gut interactions in health and disease. Antibiotic-associated diarrhoea. Best Pract Res Clin Gastroenterol 2004, 18:337-52.

8. Hori K, Yura J, Shinagawa N, Sakurai S, Mashita K, Mizuno A: Postoperative enterocolitis and current status of MRSA enterocolitis-the result of a questionnaire survey in Japan. Kansenshogaku Zasshi 1989, 63:701-7 (in Japanese).

9. Imai S, Sato T, Kunimatsu M, Tanaka H, Kato K, Akutsu M, Tanaka T: Hospital acquired infection in surgical field and its countermeasure present situation of anaerobes, P. aeruginosa and MRSA infection. Nihon Geka Gakkai Zasshi 1992, 93:906-9 (in Japanese).

10. Iwai S, Akutsu M: Severe infection in gastroenterological field; MRSA (methicillin resistant Staphylococcus aureus) enterocolitis. Nippon Rinsho 1994, 52:456-61 (in Japanese).

11. Kellum JA, Uchino S: International differences in the treatment of sepsis: are they justified? JAMA 2009, 301:2496-7.

12. Rogers BA, Hayashi Y: An oral carbapenem, but only now intravenous penicillin: the paradox of Japanese antimicrobials. Int J Infect Dis 2012, 16:e830-e832.

13. Japan Medical Abstract Society Homepage. http://www.jamas.or.jp/ service/index.html (last accessed: April 17, 2013. in Japanese).

14. Desnues B, Al Moussawi K, Raoult D: Defining causality in emerging agents of acute bacterial diarrheas: a step beyond the Koch's postulates. Future Microbiol 2010, 5:1787-97.

15. Högenauer C, Langner C, Beubler E, Lippe IT, Schicho R, Gorkiewicz G, Krause R, Gerstgrasser N, Krejs GJ, Hinterleitner TA: Klebsiella oxytoca as a causative organism of antibiotic-associated hemorrhagic colitis. N Engl $\int$ Med 2006, 355:2418-26.

16. Cohen SH, Gerding DN, Stuart Johnson M, Kelly CP, Loo VG, McDonald LC, Pepin J, Wilcox MH, Society for Healthcare Epidemiology of America; Infectious Diseases Society of America: Clinical Practice Guidelines for Clostridium difficile Infection in Adults: 2010 Update by the Society for Healthcare Epidemiology of America (SHEA) and the Infectious Diseases Society of America (IDSA). Infect Control Hosp Epidemiol 2010, 31:431-55.

17. George WL, Sutter VL, Citron D, Finegold SM: Selective and differential medium for isolation of Clostridium difficile. J Clin Microbiol 1979, 9:214-9.

18. Shetty N, Wren MWD, Coen PG: The role of glutamate dehydrogenase for the detection of Clostridium difficile in faecal samples: a meta-analysis. J Hosp Infect 2011, 77:1-6. 
19. Izumida S, Kato H, Hashimoto S, Nakamura M: [Comparison of rapid tests of toxin A and glutamate dehydrogenase and culture for detection of Clostridium diffcile]. Nihon Shokakibyo Gakkai Zasshi 2005, 102:1004-9 (in Japanese).

20. Kikkawa H, Hitomi S, Watanabe M: Prevalence of toxin A-nonproducing/ toxin-B-producing Clostridium difficile in the Tsukuba-Tsuchiura district, Japan. J Infect Chemother 2007, 13:35-8.

21. Kimata $\mathrm{H}$ : A case of MRSA enterocolitis in an infant, probably due to colonization from the hand of the mother, successfully treated with vancomycin. Medical Frontline 1999, 54:148-149. in Japanese.

22. Kimata H, Kawahara M: Methicillin-resistant Staphylococcus aureus enteritis in an immunologically uncompromised infant. Eur J Pediatr 1999, 158:431.

23. McDonald M, Ward P, Harvey K: Antibiotic-associated diarrhoea and methicillin-resistant Staphylococcus aureus. Med J Aust 1982, 1:462-4.

24. Christie CD, Lynch-Ballard E, Andiman WA: Staphylococcal enterocolitis revisited: cytotoxic properties of Staphylococcus aureus from a neonate with enterocolitis. Pediatr Infect Dis J 1988, 7:791-5.

25. Sakamoto N, Take S, Kawahara M, Kawahara K, Ohi Y: Postoperative MRSA enterocolitis. Medicament News 1990, 1288:5-7 (in Japanese).

26. Matsuo S, Aihara M, Takahashi H: Clinical and pathological study of 34 patients with isolation of methicillin-resistant Staphylococcus aureus in stool culture. Kansenshogaku Zasshi 1991, 65:1394-402 (in Japanese).

27. Nakashio T, Shimada J, Yukutake N, Shimomura H, Inoue K, Terasawa K, Mizushima Y, Harasawa I, Koseki A, Endo M, Watanabe K, Kusakari K: Clinicopathological investigation on a case of methichillin-resistant Staphylococcus aureus (MRSA) enterocolitis. Igaku to Yakugaku 1991 25:1421-1426 (in Japanese).

28. Takeshima T, Hashimoto H, Noro T, Takahashi T, Hino Y, Hirashima T, Watanabe J, Hagi H, Tsuji T, Yamashiro M: Postoperative enterocolitis due to Methicillin resistant Staphylococcus aureus and Clostridium difficile in Abdominal Surgery. Nihon Geka Kansensho Kenkyu 1991, 3:199-202 (in Japanese).

29. Ueda H, Todoroki T, Fukao T, Matsuda M, Kawashima T, Nozue M, Osada A, Kato S, Shibuya S, Ishikawa A, Takase Y, Iwasaki Y: Experiences of 2 cases of postoperative enteritis caused by Methicillin Resistant Staphylococcus Aureus (MRSA). Nihon Geka Kansensho Kenkyu 1991, 3:208-213 (in Japanese).

30. Hanatani Y, Hasumi T, Asagoe T, Miyoshi H, Otsuka M, Sekine M, Takami H, Kodaira S, Kawakami S, Ubukata K, Konno M: A case report of postoperative MRSA enterocolitis: enzymatic detection of polymerase chain reaction for early diagnosis of MRSA. Jpn J Chemother 1992, 40:1371-1375 (in Japanese).

31. Inamatsu T, Ooshima H, Masuda Y, Fukayama M, Adachi K, Takeshima H, Hashimoto $\mathrm{H}$ : Clinical spectrum of antibiotic associated enterocolitis due to methicillin resistant Staphylococcus aureus. Jpn J Clin Med 1992, 50:1087-1092 (in Japanese).

32. Masuda H, Aoki Y, Adachi S, Suga J, Tabata M, Momii M: A case of MRSA enterocolitis after gastrectomy. Surgery 1993, 55:591-594 (in Japanese).

33. Taylor M, Ajayi F, Almond M: Enterocolitis caused by methicillin-resistant Staphylococcus aureus. Lancet 1993, 342:804.

34. Takatera H, Nishimura K, Miura H, Fujioka H: MRSA Enteritis Associated with surgically treated urological diseases. Med J Osaka Pol Hosp 1994, 18:23-26 (in Japanese).

35. Kuramoto I, Nakgawa Y, Yamada Y, Miyamoto N, Sakata T: A study of 36 cases of cultured methicillin-resistant Staphylococcus aureus (MRSA) in stool. Jpn J Chemother 1996, 44:560-562 (in Japanese).

36. Watanabe H, Sato S, Kurita S, Sato A, Yoshimine H, Tanaka H, Suenaga N, Watanabe K, Rikitomi N, Nagatake T: Clinical study of 18 patients whom MRSA was detected from stool-especially about comparison enterocolitis with colonization. Kansenshogaku Zasshi 1996, 70:1170-5.

37. Konishi T, Idezuki Y, Kobayashi H, Shimada K, Iwai S, Yamaguchi K, Shinagawa N: Oral vancomycin hydrochloride therapy for postoperative methicillin-cephem-resistant Staphylococcus aureus enteritis. Surg Today 1997, 27:826-32.

38. Sakai Y, Yamamoto S, Hatakeyama K: Enterocolitis due to MRSA and Clostridium difficile after Gastrointestinal Surgery. Niigata lgakukai Zasshi 1997, 111:626-630 (in Japanese).

39. Yoshida T, Kikuchi Y, Satoh H, Andoh Y, Tsuchiya A, Abe R: A Case of MRSA Infection with Hemorrhagic Enterocolitis after Surgery for Rectal Cancer. J Jpn Surg Assoc 1997, 58:2267-2272 (in Japanese).
40. Schiller B, Chiorazzi N, Farber BF: Methicillin-resistant Staphylococcal enterocolitis. Am J Med 1998, 105:164-6.

41. Gravet A, Rondeau M, Harf-Monteil C, Grunenberger F, Monteil H, Schieftel JM, Prévost G: Predominant Staphylococcus aureus Isolated from Antibiotic-Associated Diarrhea Is Clinically Relevant and Produces Enterotoxin A and the Bicomponent Toxin LukE-LukD. J Clin Microbiol 1999, 37:4012-9.

42. Terada K, Niizuma T, Ogita S, Tanaka H, Kataoka N: A case of severe enterocolitis in an infant caused by methicillin resistant Staphylococcus aureus. Bacteriocidal effects of neutrophil and its relationship. Japanese J Pediatr 2000, 53:1465-1468 (in Japanese).

43. Watanabe H, Masaki H, Asoh N, Watanabe K, Oishi K, Kobayashi S, Sato A Nagatake T: Enterocolitis caused by methicillin-resistant Staphylococcus aureus: molecular characterization of respiratory and digestive tract isolates. Microbiol Immunol 2001, 45:629-34

44. Yanagi Y, Kubota T, Matsui K, Kadokura Y, Hanaoka H: Enterocolitis Caused by Methicililn Resistant Staphylococcus aureus (MESA) after Bilateral Neck Dissection. Jibi-Inko-Rinsho 2002, 95:409-412 (in Japanese).

45. Igami T, Hasegawa S, Ogiso E, Sakamoto E, Ohira S, Mori T, Hattori K, Mizuno T, Sugimoto M, Fukami Y: A clinical study of methicillin-resistant Staphylococcus Aureus Enterocolitis after Gastroenterological Surgery. Geka 2002, 64:338-341 (in Japanese).

46. Lee HL, Han DS, Kim JP, Kim JB, Park JY, Sohn JH, Hahm JS: A case of methicillin resistant Staphylococcus aureus enterocolitis presenting with massive diarrhea. Korean J Gastroenterol 2003, 42:246-8 (in Korean).

47. Fujita $\mathrm{K}$, Honda $\mathrm{Y}$, Kurihara $\mathrm{T}$, Ohba H, Okimoto N: A case of Pseudomembranous Enterocolitis caused by Methicillin-resistant Staphylococcus aureus. Kansenshogaku Zasshi 2004, 78:905-909 (in Japanese).

48. Yoshida T, Yokoo N, Kimoto M, Adachi T, Tanaka Y, Hamasu S, Nagata H, Kitamura K: A Patient with Pseudomembranous enteritis and penetrating necrosis who difficult to select a reasonable surgery. Jpn J Gastroenterol Surg 2004, 37:721-726 (in Japanese).

49. Froberg MK, Palavecino E, Dykoski R, Gerding DN, Peterson LR, Johnson S: Staphylococcus aureus and Clostridium difficile cause distinct pseudomembranous intestinal diseases. Clin Infect Dis 2004, 39:747-50.

50. Rhee KY, Soave R, Maltz C: Methicillin-resistant Staphylococcus aureus as a cause of antibiotic-associated diarrhea. J Clin Gastroenterol 2004, 38 (3):299-300

51. Nishizawa K, Terasaka S, Hirai E, Kuga Y: A Case of Shock and DIC because of MRSA Enteritis during the medical treatment of odontogenic infection. J Kyushu Dental Society 2005, 59:22-26 (in Japanese).

52. Ackermann G, Thomalla S, Ackermann F, Schaumann R, Rodloff AC, Ruf BR: Prevalence and characteristics of bacteria and host factors in an outbreak situation of antibiotic-associated diarrhoea. J Med Microbiol 2005, 54:149-53.

53. McPherson S, Ellis R, Fawzi $H$, Panter SJ: Postoperative methicillin-resistant Staphylococcus aureus enteritis following hysterectomy: a case report and review of the literature. Eur J Gastroenterol Hepatol 2005, $17: 1225-7$

54. Boyce JM, Havill NL: Nosocomial antibiotic-associated diarrhea associated with enterotoxin-producing strains of methicillin-resistant staphylococcus aureus. Am J Gastroenterol 2005, 100:1828-34.

55. Asha NJ, Tompkins D, Wilcox MH: Comparative analysis of prevalence, risk factors, and molecular epidemiology of antibiotic-associated diarrhea due to Clostridium difficile, Clostridium perfringens, and Staphylococcus aureus. J Clin Microbiol 2006, 44:2785-91.

56. Kurabayashi H, Sasaki M, Izawa K, Oturu M, Kaneko A: A case of postoperative MRSA wound infection and enteritis of mandibular bone ameloblastoma successfully treated with linezolid. Oral Therap Pharmacol 2007, 26:28-31. in Japanese.

57. Nagao T, Uematsu D, Sekine T, Hasegawa T, Okada K, Ooi E: Two similar acute exacerbation cases of methicillin-resistant Staphylococcus aureus enterocolitis occurred after colorectal surgery. Geka 2007, 69:1111-1114 (in Japanese).

58. Flemming K, Ackermann G: Prevalence of enterotoxin producing Staphylococcus aureus in stools of patients with nosocomial diarrhea. Infection 2007, 35:356-8.

59. Kotler DP, Sandkovsky U, Schlievert PM, Sordillo EM: Toxic shock-like syndrome associated with staphylococcal enterocolitis in an HIV-infected Man. Clin Infect Dis 2007, 44:e121-e123. 
60. Shiraishi T, Taniguchi K, Murahashi S, Shimizu T, Yokoyama H: Current Status of Oral Vancomycin Therapy for Infectious Enterocolitis. J Jpn Soc Hosp Pharm 2008, 44:1515-1518.

61. Tamura J, Kitaguchi K, Sakikubo M, Kamimura R, Ooe H, Yoshikawa A, Ishigami S, Baba N, Ogawa H, Sakanashi S: A study on pseudomembranous colitis and MRSA enterocolitis in surgical in patients who were treated with oral administration of vancomycin. $J$ Jpn Surg Assoc 2008, 69:1565-1572 (in Japanese).

62. Dalal A, Urban C: Enterocolitis caused by methicillin-resistant Staphylococcus aureus. Infect Dis Clin Pract 2008, 16:222-223.

63. Lo TS, Borchardt SM: Antibiotic-associated diarrhea due to methicillinresistant Staphylococcus aureus. Diagn Microbiol Infect Dis 2009, 63:388-9.

64. Fujii $Y$, Takagi l: A case of pneumatosis cystoides intestinalis associated with MRSA enteritis. J Jpn Surg Assoc 2010, 71:3158-3161 (in Japanese).

65. Kitahata Y, Nakamura M, Iwahashi M, Nakamori M, Ojima T, Yamaue H: A case of pseudomembranous enterocolitis caused by methicillin-resistant Staphylococcus aureus in the interposed ileum after esophagectomy. J Jpn Surg Assoc 2011, 72:2524-2529 (in Japanese).

66. Rainard P, Corrales J-C, Barrio MB, Cochard T, Poutrel B: Leucotoxic Activities of Staphylococcus aureus Strains Isolated from Cows, Ewes, and Goats with Mastitis: Importance of LukM/LukF?-PV Leukotoxin. Clin Diagn Lab Immunol 2003, 10:272-7.

67. PROHASKA JV: Pseudomembranous enterocolitis; the experimental induction of the disease with Staphylococcus aureus and its enterotoxin. AMA Arch Surg 1959, 79:197-206.

68. Kawai K: Experimental Studies on postoperative enterocolitis with methicillin-resistant Staphylococcus aureus. Jpn J Gastroentero/ Surg 1994, 27:876-883. in Japanese.

69. Ida T, Tamura A, Kawaharajo K, Shimada J: Intestinal colonization with methicillin-resistant Staphylococcus aureus in mouse. Jpn J Chemother 1994, 42:923-930 (in Japanese).

70. Hisada M, Manabe T, Kato N, Okonogi K: Studies on colonizaation of mouse caecum by methicillin-resistant Staphylococcus aureus (MRSA). Jpn J Chemother 1995, 43:193-199 (in Japanese).

71. Arima Y: Rat methicillin-resistantStaphylococcus aureus infection model demonstrating intestinal colonization and bacterial translocation. J Infect Chemother 1997, 3:154-9.

72. Yoshida Y: Methicillin-resistant Staphylococcus aureus proliferation in the rat gut is influenced by gastric acid inhibition and the administration of antibiotics. Surg Today 1999, 29:327-37.

73. Nakamura Y, Aramaki Y, Kakiuchi T: A mouse model for postoperative fatal enteritis Due to staphylococcus infection. J Surg Res 2001, 96:35-43.

74. Tanaka H, Sumiyama Y, Kusachi S, Arima Y, Yoshida Y, Nakamura Y, Nagao J, Kajiwara H, Saida Y, Usui S: MRSA enteritis and bacterial translocation. J Abdom Emerg Med 2003, 23:477-483 (in Japanese).

75. Tanaka H, Miyazaki S, Sumiyama Y, Kakiuchi T: Role of macrophages in a mouse model of postoperative MRSA enteritis. J Surg Res 2004, 118:114-21.

76. Felsen J, Wolarsky W: Epidemic diarrhea of the newborn. Arch Pediatr 1942, 59:495-512

77. Kramer IRH: Fatal staphylococcal enteritis developing during streptomycin therapy by mouth. Lancet 1948, 2:646-647.

78. Oeding P, Austarheim K: The Occurrence of Staphylococci in the Intestinal Content After Treatment with Antibiotics. Acta Pathologica Microbiologica Scandinavica 1954, 1(35):473-83.

79. Altemeier WA, Hummel RP, Hill EO: Staphylococcal Enterocolitis Following Antibiotic Therapy. Ann Surg 1963, 157(6):847-57.

80. [No author mentioned]: Antibiotics, Staphylococcal Enteritis and Pseudomembranous Enterocolitis. New England J Med 1953, 249:37-40.

81. Siegel DL, Edelstein $\mathrm{PH}$, Nachamkin I: Inappropriate testing for diarrheal diseases in the hospital. JAMA 1990, 263:979-82.

82. Lowy FD: Staphylococcal Infections. In Harrison's Principles of Internal Medicine. 18th edition. Edited by Longo DL, Fauci AS, Kasper DL, Hauser SL, Loscalzo J. New York: McGraw-Hill; 2012:1160-1170

83. Que YA, Moreillon P: Staphylococcus Aureus (Including Staphylococal Toxic Shock). In Principles and Practice of Infectious Diseases. 7th edition. Edited by Mandell GL, Bennett JE, Dolin R. Philadelphia: Churchill Livingstone Elsevier; 2010:2543-2578.

84. Liu C, Bayer A, Cosgrove SE, Daum RS, Fridkin SK, Gorwitz RJ, Kaplan SL, Karchmer AW, Levine DP, Murray BE, Rybak MJ, Talan DA, Chambers HF: Clinical practice guidelines by the infectious diseases society of America for the treatment of methicillin-resistant staphylococcus aureus infections in adults and children. Clin Infect Dis 2011. [cited 2012 Feb 14]; Available from: http://cid.oxfordjournals.org/content/early/2011/01/04/cid. ciq146.full.

85. Kato H: Didjunction of Clostridium difficile and CD check. http://www jarmam.gr.jp/situmon3/cd-check.html (in Japanese) [viewed May 23, 2013].

86. Gorkiewicz G: Nosocomial and antibiotic-associated diarrhoea caused by organisms other than Clostridium difficile. Int J Antimicrob Agents 2009, 33(Suppl 1):S37-41.

87. Lin Z, Kotler DP, Schlievert PM, Sordillo EM: Staphylococcal enterocolitis: forgotten but Not gone? Dig Dis Sci 2010, 55:1200-7.

88. Edwards LA, O'Neill C, Furman MA, Hicks S, Torrente F, Pérez-Machado M, Wellington EM, Phillips AD, Simon MH: Enterotoxin-producing staphylococci cause intestinal inflammation by a combination of direct epithelial cytopathy and superantigen-mediated T-cell activation. Inflamm Bowel Dis 2012, 18:624-40.

89. Boucher HW, Corey GR: Epidemiology of methicillin-resistant Staphylococcus aureus. Clin Infect Dis 2008, 46(Suppl 5):S344-349.

doi:10.1186/1471-2334-14-247

Cite this article as: Iwata et al:: A systematic review for pursuing the presence of antibiotic associated enterocolitis caused by methicillin resistant Staphylococcus aureus. BMC Infectious Diseases 2014 14:247.

\section{Submit your next manuscript to BioMed Central and take full advantage of:}

- Convenient online submission

- Thorough peer review

- No space constraints or color figure charges

- Immediate publication on acceptance

- Inclusion in PubMed, CAS, Scopus and Google Scholar

- Research which is freely available for redistribution 